\title{
Şanizade Mehmet Ataullah: Bir Osmanlı Tarih Tasavvur ve Yazımı Örneği*
}

\author{
Halil İbrahim Erol**
}

Öz: Tarih, muhteva itibariyle mümkinatın hallerinden oluşmaktadır. Birinci veçhesi, tahakkuk etmiş hallerden; ikinci veçhesi ise bu hallerin kayıt altına alınmasından meydana gelir. Bu zemin, varlık mertebelerinden birine denk düşmektedir. Modern tarih düşüncesinde, bu varlık zemini dâhilinden yola çıkarak tarihe dair bakış açısı geliştirilmektedir. Kadim döneme baktığımızda, bu durumun farklılık arz ettiği görülecektir. Bu çalışmada, XIX. yüzyıl başlarındaki döneme ait bir çalışma olan vakanüvislik yapmış Şanizade Mehmet Ataullah Efendi'nin Tarih-i Şanizade isimli eseri incelenmektedir. XIX. asırın başlangıcında Osmanlı tarih yazıcılığının nasıl bir varoluşsal zemin inşa ettiği ve ne tür bir yazım usulü geliştirdiği meselesi üzerinde yoğunlaşılacaktır. Mevzu, II. Mahmud döneminde yaşamış olan Şanizade'nin tarih eseri bağlamında ele alınarak aydınlatılmaya çalışılacaktır. Mümkün varlıkların hallerinin kayıt altına alınma tarzı ve hadiseleri değerlendirme biçimi, Osmanlı vakanüvis geleneğindeki varlıkbilimsel bakış açısı ve bilgikuramsal yaklaşım üzerinden tahlil edilecektir. Bu meseleler, Şanizade'nin tarih tasavvuru ve tarih yazım usulü çerçevesinde anlamlandırılmaya çalışılacaktır. Yazının temel iddiası Şanizade Tarihi'nin varlıkbilimsel ve bilgikuramsal açılardan almaşık bir değerler dizisine imkân tanımış olduğu yönündedir.

Anahtar Kelimeler: Şanizade Mehmet Ataullah, Osmanlı Tarih Yazıcılığı, Tarih Tasavvuru, Vakanüvis.

Abstract: As regards its content, history deals with states of the possibilities. One aspect of history concerns events that have actually occurred in the past; while the other involves keeping records of these events. This ground corresponds to one the ranks of being. Modern view of history has emerged out of this ground. In ancient times, however, history was perceived differently. This paper studies vakanuvis Şanizade Mehmet Ataullah's Tarih-i Şanizade (Şanizade's History), a work on early 19th century. Particularly central to this study are (i) the existential background of early 19th century Ottoman historiography, and (ii) the methods of historiography employed. The problem is addressed within the context of the historical work by Şanizade, who was contemporary with Mahmud II. Methods of recording historical events, and of assessing them, are analyzed against that background of the ontological viewpoint and the epistemological approach, dominant at the time in the Ottoman vakanuvis tradition. The issue is discussed within the framework of Şanizade's thought of history and his methods of historiography. The main argument put forth in this study is that Şanizade's History has allowed a range of alternating values from ontological and epistemological perspectives.

Keywords: Şanizade Mehmet Ataullah, Ottoman Historiography,Thought of History, Vakanuvis.

* Bu makale, Halil İbrahim Erol tarafından İstanbul Üniversitesi Sosyal Bilimler Enstitüsüne 2010 yılında sunulan yüksek lisans tezinden derlenmiştir.

** Arş. Gör., Kırklareli Üniversitesi Fen - Edebiyat Fakültesi Tarih Bölümü

Iletişim: halilibrahimerol@gmail.com, Kırklareli Üniversitesi Fen Edebiyat Fakültesi, Kavaklı, Kırklareli.

Atıf(: Erol, H. I. (2012). Şanizade Mehmet Ataullah: Bir Osmanlı tarih tasavvur ve yazımı örneği. Insan ve Toplum, 2 (3), 33-56. 


\section{Giriş}

Her medeniyet ve kültür, kendine has bir tarih anlayışı ve tarihyazım geleneği oluşturmuştur. Bu anlamda Osmanlı Devleti, uzun soluklu bir tarih yazıcılığı geçmişine sahiptir. Osmanlı İmparatorluğu'nda, neredeyse kuruluşundan itibaren, bir şekilde hadiseler kayıt altına alınmıştır. Gazavatnâme, menakıpname ve şehname türünde müstakil birçok eser yazılmıştır. Kanuni devriyle birlikte şehname tarzındaki yazım türü, kurumsallaşmış ve bir müddet sonra, yerini vakanüvislik müessesesine bırakmıştır. 'Vekayi'nüvîs' ya da sonraki kullanımıyla 'vak'a-nüvis', Osmanlı merkez teşkilatında devletin, tarihî olayları kaydetmekle görevlendirdiği kişilere verilen isimdir. Kurumsal olarak vakanüvislik, Divan- Hümayun dairesinde XVIII. yüzyıldan itibaren ihdas olunan bir memuriyettir (Pakalın, 1983, s. 574-575). Bu kurumun çatısı altında çalışan vakanüvislerin vazifesi, devletçe zabt ve tahriri, kendilerine verilen vesikaları kaydetmek olmuş ve öteden beri vakanüvisler, vekayi ceridelerini kendilerinden sonra göreve gelenlere intikal ettirmişlerdir (Ahmet Cevdet, 1986, s. 3).

Bu kurumun çatısı altında görev alan vakanüvislerle tarih yazımı, imparatorluğun sonuna kadar devam etmiştir. İki yüzyıllık (1699-1924) bir maziye sahip olan bu müessesede, daima bir vakanüvis görevde bulunmuştur. Mustafa Na'îmâ ile başlayan vakayiname tarzındaki tarih yazıcılığı, Abdurrahman Şeref'le sona ermiştir. Arap ve İran tarihçiliğinden belirli ölçüde etkilenen Osmanlı tarih yazıcılığı, nihai anlamda kendine özgü bir gelenek meydana getirmiştir. Vakanüvisler, genel itibariyle birçok noktada bu yazım kültürüne bağlı kalsalar da kendi özgünlüklerini belirli ölçüde ortaya koyma imkânı bulabilmişlerdir. Muhteviyat ve üslup açısından temelde muayyen bir seyir takip edilmesine rağmen netice itibariyle vakanüvisin kendi bakış açısına ve üslubuna göre birtakım farklılıklar ortaya çıkmaktadır. Bu çalışmada, Tarih-i Şanizade adlı eserden yola çıkılarak vakanüvis olarak II. Mahmud döneminde görevde bulunan Mehmet Ataullah Efendi'nin tarih, tasavvur ve yazım geleneği ele alınacaktır.

\section{Şanizade'nin Tarih Tasavvuru}

Şanizade Mehmet Ataullah Efendi'nin doğum tarihi hakkında kesin bir tespit yapılamamıştır. Bununla birlikte İstanbul Ortaköy'de doğduğu bilinmekte ve 1770 'li yıllarda doğduğu düşünülmektedir (İnal, 1988, s. 111). Bir diğer iddiaya göre ise 1771'den evvel doğmuş olabileceği varsayılmıştır (Zülfikar, 1991, s. 13). Şanizade, Hacı Mehmed Sâdık Efendi'nin oğlu ve Hacı Mustafa Efendi'nin torunudur. Ailenin, Şanizade ismini Ataullah Efendi'nin büyük babası olan Tarakçı Ahmed Dede'den aldığı ileri sürülmüştür. Şânî kelimesi, tarakçı kelimesinin Farsça karşıığıdır (Zülfikar, 1991, s. 13). Şanizade Mehmet Ataullah Efendi, medrese tahsilinin akabinde tarîk-i ilmiyeye intisap ederek ilmiye ruûsu almıştır (Karslızâde, 1314, s. 66). Medrese mezuniyeti sonrası Süleymaniye Tıp Medresesi'nde ve Halıcıoğlu Mühendishanesi'nde ilim tahsiline devam etmiştir 
(Zülfikar, 1991, s. 17). Süleymaniye Tıp Medresesi'nden mezun olmasına ve tıp neşriyatına rağmen sarayda veya herhangi bir darüşşifada hekim ya da tıp medresesinde hoca olduğuna dair bir kayda rastlanmamıştır (Zülfikar, 1991, s. 21).

Şanizade'nin ulûm-ı nakliye ve ulûm-ı akliyede, özellikle de tıp, teşrîh, hendese ve hey'et gibi ilimlerde nâdirü'l-akrân olduğu umumiyetle kabul görmüştür (İnal, 1988, s. 119). Eğitim hayatı sonrasında, Çorlu Medresesi Müderrisliği, Eyüp Kadılığı, Haremeyn Evkaf Müfettişliği görevlerinde bulunmuştur. (Zülfikar, 1991, s. 20-21). İlmiye sınıfına mensup Şanizade Mehmed Ataullah Efendi (ö. 1826), 1819-1825 yılları arasında vakanüvis olarak görev yapmıştır. Şanizade, diğer birçok vakanüvis gibi kendisinden önceki dönemde eksik bırakılarak yazılmamış olan evreleri kayıt altına alarak eserine başlamıştır. Kendisinden önce aynı görevi deruhte etmiş olan Mütercim Âsım Efendi, II. Mahmud'un cülusuna kadar olan vakaları kaydetmiş, geri kalan on iki yıllın zabıt müsveddelerini halefi Şanizade'ye intikal ettirmiştir (Kütükoğlu, 1994, s. 199). Şanizade, eserinde 1808-1821 tarihleri arasındaki vakaları kaleme alabilmiş, selefi devrine ait vakaları temize çekip yazmaktan kendi görev süresine denk gelen zaman dilimindeki hadiseleri tedvin ve tertibe imkân bulamamış, dolayısıyla 1821-1825 dönemine ait notlarını, Es'ad Efendi'ye devretmiştir (Kütükoğlu, 1994, s. 103-106). Tarih-i Şanizade'nin yazma halindeki nüshaları, birçok kütüphanede mevcuttur.'

Tablo 1.

Tarih-i Şanizade'nin Yıl ve Ciltlere Göre Dağılımı*

\begin{tabular}{lll}
\hline Ciltler & Kapsadığı Zaman Dilimleri & Sayfa Adedi \\
\hline Cilt 1 & $1808-1811$ & $8+409$ \\
\hline Cilt 2 & $1811-1818$ & $8+425$ \\
\hline Cilt 3 & $1818-1821$ & $4+216$ \\
\hline Cilt 4 & 1821 & $4+208$ \\
\hline
\end{tabular}

Şanizade, eserini kaleme alırken birtakım farklı kaynaklardan istifade etmiş ve eserinde edebî içerikli birçok alıntıya yer vermiştir. Şanizade, anlattığı hadiselere açıklık getirmek için alıntı yapma yolunu tercih etmiştir. Bu bağlamda şiir, atasözü ve deyim

1 Eserin basılma tarihi oldukça geç bir dönemde gerçekleşmiştir. Birinci cilt, 1284/1867-68 senesinde İstanbul'da Trabzonlu Bakırcıbaşı Mahmud Efendizade Süleyman Efendi Matbaası'nda; ikinci cilt, 1290/1873 senesinde; üçüncü cilt, 1291/1874'te; dördüncü cilt ise İstanbul'daki Cerîde-i Havâdis Matbaası'nda basılmıştır. Son ciltte basım tarihi bulunmamaktadır. Fakat üçüncü ciltle aynı senede basılmış olabileceği ihtimali ileri sürülmüştür. Bk. Yılmazer (2008, s. LXII).

* Yukarıdaki çizelgeden dönemler ve kendilerine ayrılan bölüm hacimlerine bakıldığında Woodhead'in, Lokman ve diğer şehnameciler için "anlatının, yazarın kendi zamanına ne kadar yaklaşırsa o kadar detaylandırıldığı" şeklinde ileri sürdüğü iddiasının burada da kısmen geçerli olduğu söylenebilir. Bk. Woodhead (1983, s. 174-175). 
gibi ifadelerin tespiti kolaylıkla yapılabilmektedir. Özellikle şiirlerin müellifini tayin etmek, yapılacak bir araştırmayla imkân dâhilindedir. Fakat diğer taraftan, tarihî bir hadiseyle ilgili alıntıyı tespit edip gün yüzüne çıkarmak için çok ince bir ustalığa ihtiyaç duyulmaktadır. Her ne kadar genel temayül eser isimlerini açıkça ifade etmemek olsa da Şanizade, eserinin bazı yerlerinde müellif ismi ya da kitap ismi zikretmektedir. ${ }^{2}$ Buradan yola çıkarak Şanizade'nin kullandığı kaynakları kabaca ikiye ayırmak münasip olacaktır. Eserde temel anlamda yazılı ve sözlü başlıklar altında toplayabileceğimiz iki tür kaynaktan beslenilmiştir. Yazılı kaynaklar kısmı iki başlık altında ele alınabilir. Birincisi devlet kademelerindeki resmî yazışmalardan oluşmaktadır ki eserin önemli bir yekûnu bunlardan oluşur. Diğer yazılı kaynaklar ise daha önceden kaleme alınmış telif eserlerdir. ${ }^{3}$

Şanizade, tarihe dair düşüncelerini, tarih eserinin mukaddimesinde zikretmekte ve temel anlamda tarihi üç kısma ayırmaktadır:

"Tarih ya vekayi-i hakîkiyye-i sâdıkanın yahut hikâyât-ı gayr-i vâkıa-i kâzibenin zabt u naklinden ibaret ve bazı tevârîh mebnî ale'z-zunûn olmak mülabesesiyle 'inne'z-zanne lâ yugnî mine'l-hakkı şey'en' müddeasınca ekseriya hatâyây-ı akl-ı beşer ve tasavvurât-ı adîmetü'l-vukû-i gayr-i mu'tebere ile muhtellü's-sıhhattir" (Şanizade, 2008, s. 14). ${ }^{4}$

Şanizade'ye göre tarih, gerçekleşmiş olayların doğru bir şekilde kayıt altına alınıp aktarılmasından veyahut gerçekleşmemiş hadiselerin uydurularak yazılması ve intikal ettirilmesinden müteşekkildir. Bunlar, iki uç noktayı teşkil eder. Bir üçüncü kısım ise (ya da ikinciye dâhil edilebilir) şüphe üzerine bina edilen ve zan olması itibariyle de doğruluk bakımından bir ehemmiyeti olmayan, dolayısıyla insan düşüncesindeki yanılmalar veya itibar edilmeyen ve gerçekleşmesi imkân dâhilinde olmayan tasavvurlarla doğruluğunu yitiren bir tarih aktarımıdır.

Kısaca ifade etmek gerekirse; tarihî bilgi, ya kesin doğru malumattan oluşabilir; ya şüphe barındırabilir (ki bu kısım da nihai anlamda üçüncü olana girer, kendisine itibar

2 İsim zikretmeden kaynak kullanımına örnek olarak Câbî Tarihi verilebilir. Câbî Ömer Efendi'nin kaleme aldığı eser, Mehmet Ali Beyhan tarafından neşredilmiştir. Bk. Câbî Ömer Efendi, (2003). Hem yapılan mezkûr çalışmada hem de kaleme alınan başka bir makalede Şanizade'nin Câbî Tarihi'ni kaynak olarak kullandığı ileri sürülmüştür. Beyhan, makalesinde, CâbîTarihi ile Şanizade Tarihi'ni mukayeseli olarak ele almış ve kaynak kullanımını metindeki benzerlikler üzerinden delillendirmiştir. Bk. Beyhan (1995).

3 Çelebizâde Aziz Efendi'nin tarih eserinden, Vâsıf Tarihi'nden, Meşârık-ı Şerîften Hadîkatü'l- Cevâmi' isimli eserden, Tarih-i Na 'îmâ'dan, Râşid Efendi'nin tarihinden Âsım Efendi'nin tarih kitabından, Şecere-i Ilâhiyye'den, Ahlâk-ı Celâlî̀den, Sahîh-i Buhârî́den ve Frankfurt Gazetesi'nden Tarih-i Şanizade'de istifade edilmiştir. Bk. Yılmazer (2008, s. LXXI).

4 "Tarih, doğru hakiki vakıaların veya yalan olan gerçekleşmemiş hikâyelerin yazılıp nakledilmesinden ibarettir. Bazı tarihler ise zan/şüphe üzerine inşa edilmesiyle 'zan asla gerçeğin yerini tutamaz' ifadesince çoğu zaman insan aklının yanılgıları ve itibar edilmeyen gerçekleşmemiş hadiselerin kurgulanmasıyla sıhhatini kaybederler." 
edilemez) ya da tamamen gerçek-dışı olabilir. Mehmet Ataullah Efendi, tarihin tasnifine dair yaptığı taksimatın ardından sanayi tarihinden bahsetmektedir:

"Ve tevarih-i sanayi' tabir olunur bir nev' [tür] tarih dahi vardır ki maarif ve sanayi'in icat u ihtirâ'ını havi ve menafi u fevaidi marifet ve tefehhüme bâdî ve mancınık ve âlâtını ve vücûh-i istimâlâtını tahsîl ü teallüme müeddî olmak cihetleriyle cümlesinden ziyade kesîrü'l- menfaattir" (Şanizade, 2008, s. 14). ${ }^{5}$

Konu itibariyle günümüzde bilim tarihi çatısı altında incelenen bu alan, Şanizade tarafından "edimsel" açıdan ele alınmıştır. Bu kısma, bu tür muhtevayla ilgili bir mevzunun eklemesi uygun görülmüştür. Burada sanayi tarihinin buluşlarını içeren, faydalarını anlamaya ve birtakım aletlerin nasıl kullanılacağını öğrenmeye yarayan yönlere sahip olması hasebiyle diğer tarihlerden daha fazla menfaati kendisinde bulundurduğu ifade edilir. Hâlbuki ileride zikredileceği üzere, sanayi tarihi de umumî tarihler kısmına dâhil edilmelidir.

Şanizade tarihi, özü itibariyle üç kısmın yanında, muhteviyat olarak da iki bölüme ayırmıştır. ${ }^{6}$ Birinci kısım, tevârîh-i mukaddeseden oluşur. Hz. Muhammed'in hayatı, diğer peygamberlerin kıssaları ve evliya menkıbeleri bu kısmı oluşturur. Kaynakları semavîilahî kitaplar, peygamberlerin tanıklıkları ve yüce insanların derin ilimleridir. Diğer bir ifadeyle mukaddes tarihlere vahiy, hadis ve keşif ilimleri kaynaklık etmektedir. İkinci kısım ise umumi tarihlerdir. Bunlar ise devletlerin ve onları yönetenlerin durumlarından, millet ve toplulukların yapılarından, geçmişteki işlerden ve olaylardan bahseder (Şanizade, 2008, s. 15). Buradaki sınıflandırma, İslami ilimlerdeki ikili tasnifi çağrıştırır. Söz konusu olan taksimatta, ilimler akli ve naklî olmak üzere iki kısma ayrılmıştır. Naklî ilimlerde, tefsir ve hadis gibi nesilden nesle aktarılan ilimlere yer verilmiştir. Diğerinde ise insan düşüncesiyle ortaya çıkmış ilimler yer almaktadır. Buna felsefe, mantık ve matematik gibi ilimler örnek olarak verilebilir.? Şanizade, böyle bir taksimatı tarih ilmi-

5 "Ve sanayi tarihleri şeklinde isimlendirilen bir tür tarih daha vardır ki maarif ve sanayinin icat ve benzersiz buluşlarını içerme; yarar ve faydalarını bilme ve anlamaya sebep olma; mancınık ve aletlerini, kullanış usullerini öğrenme ve bilmeye vesile olma yönleriyle tümünden [diğer tarihlerden] daha çok faydalıdır."

6 Ahmet Midhat da tarihi, tarih-i mukaddes, tarih-i tabii ve tarih-i medeni olmak üzere üç kısma ayırmıştır. Tarih-i mukaddes, Şanizade'nin tasnifinde olduğu gibi, son peygambere kadar yaşamış diğer peygamberleri, semavi kitapları, enbiyanın mucizelerini, evliyanın kerametlerini, diğer bir ifadeyle beşeriyetin gücü dışında meydana gelebilecek olayları anlatır. Benzer şekilde Süleyman Hüsnü Paşa, Tarih-i Âlem isimli eserinde tarihi, tarih-i mukaddes ve tarih-i temeddün olarak ikiye ayırmaktadır. Tarih-i mukaddesi, tarih-i enbiya ve siyer-i nebi şeklinde ikiye; tarih-i temeddünü ise, siyasi tarih, edebiyat tarihi ve tabiî tarih olmak üzere üç kısma ayırmaktadır. Bk. Nakıp $(2006$, s. 56, 83).

7 İslam ilim geleneğinde "bütün ilimler esasta akli ve naklî (dine dayalı) olmak üzere iki kısımda mütalaa edilmiştir. Bu durum, ulemanın faaliyet sahasını belirlemekte ve yönlendirmekte mühim bir rol oynamış olmalıdır. Bu sahanın seçiminde, ilimlerin gayesi oldukça belirleyici bir amil olarak görülebilir. İslam dünyasında daha ilk dönemlerden itibaren, ilimlerin bir grubu vahiy (din), ikinci grubu ise insan zekâsının ve tecrübesinin ürünü olarak düşünülmüş ve vahye dayanan ilimler nesilden nesile aktarıldıkları için, umumiyetle naklî; ötekiler ise akli olarak adlandırılmıştır. Nitekim Osmanlı medre- 
ne uyarlamıştır denebilir. Fakat yine de tam bir uyumdan söz edilemez. Çünkü varlıkbilimsel olarak ilahî kaynaklı ilimlerin etrafında teşekkül eden tarih anlatıları ile toplumsal veya siyasal içerik barındıran ve kaynağı insanın gözlem ve araştırmaları üzerine bina edilmiş olan aktarımlardan oluşan umumi tarihlerin, çoğu noktada iç içe geçmesi söz konusudur. Bunlar, nihai anlamda bir bütün olarak tarih anlatımı çerçevesine dâhil edilirler. Fakat dayandığı kaynaklar itibariyle kısmen de olsa bu tarz bir tasnife makuliyet alanı açılabilir. Çünkü birincisinde doğaötesi dünya mevcuttur ve anlatının merkezini oluşturur. İkincisi ise daha çok görünen dünya ile irtibatlıdır ve doğaötesi öğeleri hemen hemen hiç barındırmamaktadır.

Osmanlı'daki tarih aktarımdaki ana gaye genellikle nasihat ve ibret kavramları etrafında oluşmuştur. Tarih yazıcılığındaki bu amacın Kur'an'daki geçmiş olayların aktarılış sebebiyle örtüştüğü söylenebilir. Kur'an'ın birçok yerinde, geçmişte yaşamış topluluklarla ilgili hadiseler anlatılır ve insanların bunlardan ibret alması beklendiği zikredilir. Mezkûr durum, daha çok ahlaki temelde işlenir. Osmanlı geleneğinde ise işin içine siyasi unsurlar ve meşrulaştırma vasıtaları da girmektedir. Başka bir deyişle hem dinî hem de dünyevi olana yönelik bir aktarım kültürü inşa edilmiştir. Şanizade de eserinin mukaddimesinde tarih aktarımına dair benzer ifadeleri zikreder:

"Tarihin hakikati, pederânın evlâd u ahfadına zamanlarının vukuat ve hadisatını havas-ı müştereke-i beni âdeme onlar münafi olmadıkları halde karnen ba'de karnin ibret olmak için bi-hakikatihim nakl ü hikâyetleridir. Şu kadar vardır ki hakikat-i mezbure her bir karn mürurunda suret-i imkân ve kabiliyetinin bir derecesini fevt ve izaa ederek böyle gittikçe mu'telletü'l- akîbe olur" (Şanizade, 2008 , s. 15). ${ }^{8}$

Şanizade, önceki nesillerin kendinden sonrakilere, yaşadıkları dönemin olaylarını hakikatleriyle birlikte ibret için aktarması gerektiğinden bahseder. Aksi takdirde, zamanla gerçeklerin anlatılabilme ve aktarılabilme imkân ve kabiliyetlerini kaybederek nihayetinde yok olup gideceğini belirtir.

Dolayısıyla olayların sağlıklı ve vazıh bir şekilde aktarılabilmesi için bir an önce kayıt altına alınmaları icap eder. Vakanüvislik müessesesinin tam anlamılla bunu yerine getirmeye çalıştığı görülmektedir. Ataullah Efendi, olayların zamanında aktarılmamasının neticesinde "... evâ'il-i ekser-i düvel havârıkla muttasıfa"9 olacağını ifade eder (Şanizade, 2008, s. 15). Diğer bir ifadeyle, geçmişin zamanında kayıt altına alınmaması

selerine tayinleri öngörülen müderrislerin çoğunun, akliyyât ve nakliyyât ilimlerini iyi bilen insanlar olarak tavsif edilmeleri, bu anlayışın tezahüründen başka bir şey olmamalıdır" Bk. Unan (2003, s. 20).

"Tarihin hakikati, babaların çocuk ve torunlarına zamanlarının olay ve hadiselerini insanoğlunun ortak hislerine zıt olmayacak şekilde çağ çağ ibret olmak için hakikatleriyle aktarma ve anlatmalarıdır. Şu kadar var ki bu hakikatler her bir çağın/vaktin geçmesiyle imkân yolunu ve kabiliyetini bir derece yitirerek gittikçe sorunlu hale gelirler."

"...çoğu devletin başlangıcı efsanelerle betimlenir." 
halinde, sonradan o dönemlerin harikalarla (üstûre ve efsaneler) açıklanmaya çalışıldığına, kadim Yunan dönemini örnek gösterir.

Şanizade, geçmişe ve bilinebilirliğine dair üç kanıttan bahsetmektedir. Bunlar, inkârı mümkün olmayan delil ve eserlere dayandırılır. Birinci delili, Babil'de kayıt altına alınmış gökbilimle alakalı rasathane gözlemleri oluşturur. Bunların bin dokuz yüz seneyi kapsaması ve İsa'nın doğumundan iki bin iki yüz otuz sene öncesine uzanmasının, yıldız ve gökcisimleriyle ilgili yazılı kayıtlardan anlaşıldığı ileri sürülür. İkinci delilde ise Çin'den bahsedilmektedir. Geçmişinin milattan önce iki bin iki yüz elli sene öncesine uzandığı ve Babil'in muadili olduğu söylenir. Ve gökbilim uzmanları arasında bu şekilde itibar edildiği aktarılır. Şanizade, ilk iki delili kuvvetli olarak zikretmektedir. Bunları da nihai olarak rasathane kayıtlarına ve gökbilim uzmanlarının (erbâb-ı hey'et ve ehl-i tencîm) görüşlerine dayandırmaktadır. Üçüncü delilde, diğer ikisinden daha zayıf olmakla birlikte, Thomas Howard'ın (1585-1646) Akdeniz'deki Bare Adası'nda bulduğu mermer üzerine yazılmış kitabelerden Atina şehrinin tarihinin milattan önce iki yüz altmış üç sene öncesine uzandığının anlaşıldığı belirtilir. Üç delile ilaveten eserde, Mısır piramitlerinin yazılıp kayıt altına alınmasının, zamanların tümünü öncelendiği ileri sürülür. Ancak, bu delilin, bazı toplumların geçmişlerini ispatlamaktan öte bir faydası olmadığı iddia edilir. Devam eden izahatta ise bunların ötesine geçen devirlerle ilgili değerlendirmelerde bulunulur:

"Iş̧e tevârih-i 'âmme-i kadîmede mazbut oldukları mümteni'u'l-inkâr evkât-ı ma'lûme ancak bu mezkûrâttır. İmdi cemî tevârih-i 'âmme-i kadîme, hılkat-i 'âleme nazaran karibü'l-'ahd ve cedid ve takriben dört bin seneden mukaddemi mübîn olur tarih, 'adîm ve nâ-bedîd olmağla, müddet-i mezkûreden evvel olan ahvâl-i a'vâmm u ümeme ıttılâ'a 'ukûl-i benî âdem gayr-i muktedir ve havâdisât-ı piş̧în-i âlemden akl-ı me'âş-ı beşer kâsır olmaktan nâşî, anlar ta'lîm-i ümmet zımnında min kıbeli'r-Rahmân vahyolunan âyât-ı Kur'an-ı azîmü'ş-şân ve ehâdis-i şerîfe-i hazret-i Mefhâr-i dü-cihan ve ahbâr-ı sâdıka-i kütüb-i semaviye ve ilhâmât-ı peygamberân-ı zî-şânla malum olup, bunlardan başka hiçbir vechile bilinmezler" (Şanizade, 2008, s. 17-18). ${ }^{10}$

Netice itibariyle Tarih-i Şanizade'de, inkârı mümkün olunamayacak şekilde bilinebilecek tarihlerin bunlarla sınırlı olduğu ve dünyanın yaratıış̧ına nazaran kadim umumi tarihlerin daha yakın bir zaman dilimini oluşturduğu belirtilir. Açıklamanın devamında, yaklaşık dört bin sene öncesi dönemlere dair tarihî hadiseleri öğrenmenin insanın güç yetireme-

10 “îşte kadim umumî tarihlerde kaydedilmiş, inkârı mümkün olmayan malum zaman dilimleri sadece bu zikredilenlerdir. İmdi kadim umumi tarihlerin tümü, âlemin yaratılışına nazaran daha yakın ve yeni devir ve yaklaşık dört bin sene öncesi aşikâr olan tarihler yok olduğundan ve kaybolduğundan zikredilen zaman diliminden önceki millet ve halkları bilmeye insanoğlunun aklının güç yetiremeyeceğinden ve âlemin öncesindeki hadiselere insan aklının ermeyeceğinden dolayı; onlar, ümmeti eğitme maksadıyla Allah tarafından vahyolunan Kur'an-ı Kerim ayetleri, iki cihanın övünç kaynağı peygamberin hadis-i şerifleri, semavî kitapların doğru haberleri ve şan sahibi peygambere malum olan ilhamlar olup bunun dışında hiçbir şekilde bilinemezler." 
yeceği bir durum olduğu, dolayısıyla da bunların ancak vahiy, hadisler, semavi kitapların bildirdikleri ve peygamberlerin aktardıkları malumatlarla bilinebileceği ifade edilir.

Bu açıklamalar bize Şanizade'nin varoluşsal duruşunu okuyabilme imkânı verir. Vakanüvislik geleneğinde, müessesesinin yapısı gereği umumi tarih eserleri telif edilmemiştir. Bundan ötürü, örneğin bir vakanüvis olan Şanizade'nin varoluşsal bakış açısını ancak eserinin tarihle ilgili mukaddime kısmından istihraç edebiliyoruz. Bunun ötesinde, metinde geçen olaylarla irtibatlı zikredilen alıntılardan birtakım tespitler yapmak mümkündür.

Şanizade zikrettiği üç delille, geçmişin ne kadar ve ne şekilde bilinebileceğini göstermeye çalışır. Bahsettiği delil, tarihe yardımcı bir alan olarak kabul edilebilir. Şanizade'nin XIX. yüzyıl başlarında bunları yazması iki önemli duruma işaret eder: Birincisi, o dönemdeki tarih tasavvurunun ve malumatının bir vakanüvis açısından ne şekilde olduğunu gösterir. İkincisiyse mevcut tarih yazım geleneği dışına çıkan bir bakış açısına işaret eder. Şanizade'nin geçmişin tespitine dair öne sürdüğü deliller, gökbilim çalışmalarının kayıtlarına dayanmaktadır. Bu tür tahlillerin kendi dönemi itibariyle "bilimsel"/ilmî veriler olduğu düşünülürse, Şanizade'nin yadsınması mümkün olmayacak delilleri sıralamaya çalıştığı görülecektir. Şanizade, bu noktada oldukça somut deliller üzerinden geçmişe yönelik bakış açısı geliştirir. Oysa genelde geçmiş dönemlerle ilgili efsane türünden birçok açıklamaya başvurulduğu bilinmektedir. Şanizade'nin o dönemlere dair herhangi bir tarih eserinin telif edilmediğini düşünerek oradaki boşluğu somut çalışmalarla doldurmaya çalıştığı söylenebilir. Kendisinin olayların zamanında aktarılmamasının sonuç itibariyle "... evâ'il-i ekser-i düvel havârıkla muttasıfa" olacağı yönündeki tespitinin, bu bağlamda ortaya çıktığı düşünülebilir. Ve sorunun farklı deliller üzerinden aşılması yönündeki bir çabanın göstergesi olarak kabul edilebilir.

Şanizade'ye göre tarih ilminde, şerî̀ deliller veya matematik ilimleri ya da hendese usulleriyle ispatlanamayan durumlar "imkân" suretinde değerlendirilir. Tarih ilminde imkândan başka güvenilir sağlam bir delil bulunmamaktadır. Dolayısıyla da tarihî bir meseleye dair külli bir itimat (makuliyet) arama zarureti gerekli değildir (Şanizade, 1290, s. 11). Burada imkândan kastedilen şey, bir durumun gerçekleşebilirliğinin mümkinâtıdır; bir şeyin akledilebilmesidir. Göreceli olan bir durum, makul çerçeve içinde mülahaza edilir. Tarihî olayların sınanması veya müspet ilimlerdeki gibi ele alınıp vazıh bir sonuca varılması muhal olduğundan kendi makuliyetleri içinde ele alınmaları icap eder. Çünkü tarih, özü itibariyle cüzi hadiselerin toplamından oluşur. Aslında bu mesele, XIX. yüzyılda ortaya çıkan tarih tartışmalarının temelinde olan bir mevzudur ve duyguculuk ve tarihselcilik (historismus) gibi okulları olguculuğa karşı tepki olarak ortaya çıkarmıştır. Şanizade'nin kendi tabiriyle ifade etmeye çalıştığı konu da hemen hemen aynı tartışmaya tekabül etmektedir ki henüz o dönemde bu tür teorik/nazari münazaralar yoktu.

Özetle ifade etmek gerekirse, tarih ilminin muhtevasını oluşturan olayların tümünün kayıt altına alınamamış olması, kadim dönemlerin insanın kendi çabalarıyla bileme- 
yeceği gerçeğini ortaya çıkarmıştır. XIX. yüzyılın başlarında ileri sürülen bu sorunların birtakım yeni aşamalar kaydedilmekle birlikte pek de aşılabildiğini söylemek mümkün görünmemektedir. Kadim dönemlere ait arkeolojik çalışmalar, her gün yeni bir mesafe katetmektedir. Fakat nihai anlamda yazılı olarak kayıt altına alınan tarihsel bir dönemle kıyaslandığında, Şanizade'nin tabiriyle "nâ-bedîd" kalmaya devam edecektir. Ataullah Efendi, tam bu noktada devreye ilahî kaynakları dâhil ederek nihai anlamda daha şümullü bir tarih içeriğine sahip olunacağını ileri sürer. Akli olanla naklî olanı birleştirerek insanlık tarihinin muhtevasının tamamlanacağını düşünür. Oysaki günümüz tarih anlayışında, sadece akli olanla yola çıkılarak bir tarih tasavvuru ortaya konulmaya çalışılmaktadır. "Doğaötesi" unsurlar mümkün mertebe anlatı-dışı bırakılmaktadır. Burada, Osmanlı́nın genel anlamda tarih düşüncesinin; özelde ise vakanüvislik müessesesinin tarihe bakış açısının, çağdaş tarih yazıcılığından hem varlıkbilimsel hem de bilgikuramsal olarak ayrıldığı görülmektedir. Şanizade'nin eserinde, günümüzde mevcut olmayan varoluşsal bir zeminden hareketle tarihi yorumlamaktadır. Yaratıcı, nihai takdir sahibidir ve tarih onun kanun ve nizamı çerçevesinde oluşmaktadır:

"Çünkü hazret-i Fâ'il-i mutlak, 'âdet-i ilahiyye ve meşiyyet-i ezeliyyesi muktezâsınca, vukû'ât-ı 'âlem-i kevn ü fesâdı, esbâb-ı hafiye-i ba'îde ve esbâb-ı zâhire-i karîbeye ${ }^{11}$ metbû' u mu'allak edegeldiği, ehl-i tahkîk 'indlerinde müsellem ve müttefaktır" (Şanizade, 2008, s. 33). ${ }^{12}$

Şanizade, ilahî âdet ve ezelî takdirin bir gereği olarak mutlak tasarruf sahibinin, dünyadaki oluş ve bozuluşları, uzak veya gizli, yakın ve görünür sebeplerle bağlantılı olarak gerçekleştirdiğinin, işin erbabınca bilindiğini ifade eder. Böylece geçmiş/tarihin levh-i mahfûz'un gerçekleştiği döneme tekabül ettiği söylenebilir.

Diğer taraftan Şanizade, tarihçi geçinen müverrihlerin (müteverrih) hususiyetlerinden bahsederken şunları zikretmektedir: Bu tür tarihçiler, "umumi tarihlerini yazmaya giriştiklerinde devlet ve milletlerin a'zam-ı eczasının hukukunu, kanunlarını, âdetlerini, ahlak ve tabiatlarını ve bu hususların tebeddülatını ve esbâb-ı inkıâbâtını beyan etmekten kaçınmışlar ve önemli özelliklerini ifade etmekten çekinerek sadece günlük münferit olayları yazmaya yönelmişlerdir" (Şanizade, 2008, s. 22-23). Şanizade, kendi eserini kaleme alırken (ki bu eser umumi olmasa da umumi Osmanlı tarihinin bir parçasıdır) Osmanlı́nın kanun, âdet, ahlak veya tabiatındaki değişim ve dönüşümlere, özellikle de onların sebeplerine, amil ya da etkenlerine yönelik kısmi değerlendirmelerde bulunmuştur. Bu tür değerlendirmeleri, bir başka başlık altında ele alınacaktır. ${ }^{13}$

11 Çünkü "Allah, bir şeyin olmasını murâd ettiği zaman onun sebeplerini yaratır." Bk. Şanizade (2008, s. 33).

12 "Çünkü mutlak failin [kayıtsız eyleme geçenin] ilahî âdeti ve ezelî iradesi gereğince âlemin oluş ve bozuluş hadiselerini, uzak ve gizli sebeplere; yakın ve görünür nedenlere bağladığı araştırmacı kimseler tarafından kabul edilmiş ve [ve bu hususta] fikir birliğine varılmıştır."

13 Bk. Şanizade (2008, s. 16-22). 


\section{Şanizade'nin Tarih Yazım Usulü}

Osmanlı tarihçiliği, bir tarih yazım geleneği olarak temelde iki başlık altında değerlendirilir. Bunlardan ilki, ilmî tarihçilik olarak isimlendirebileceğimiz klasik İslam tarihçiliğidir. ${ }^{14}$ Diğeri ise edebî tarihçilik olarak adlandırılabilecek bir başka yazım geleneğidir. Bu gelenek, Farsçanın ve eski İran efsanelerinin yeniden ortaya çıkış evresinde doğmuştur. Kaynağı çok önemli görülmeyen ya da kaynağın güvenilir olup olmadığına ehemmiyet verilmeyen, gerçeğin araştırılıp bulunması yerine ahlakî telkinlerin gaye edinildiği, ilmî tarihçiliğin sade dil ve üslubu yerine tumturaklı, külfetli ve belagatli bir dilin tercih edildiği bir ikinci geleneğin de Osmanlı'ya tesiri söz konusudur. ${ }^{15}$

Arapça ve Farsça yazılan tarihlerdeki dil farklılığı, salt lisani farklııı olarak düşünülemeyeceği ileri sürülür. Çünkü her iki dil de belirli bir kültürel geleneğe, neredeyse başlangııından itibaren saygın bir yer vermiştir. Farsça yazan tarihçiler, Arapça yazanlara nazaran yeni Sasani kültürüne ait temaları daha fazla işlemişlerdir. İki gelenek, aynı zamanda zamandizimine dair yaklaşımlarında birbirlerinden ayrılmaktadırlar. Arapça yazan tarihçiler mümkün olduğunca kesin olmaya gayret ederek hadisenin meydana geldiği yılı, ayı, günü kaydetmeye çalışmışlardır. Zamandizimsel kesinliğe dair hassasiyetleri, bir yıllık çerçeve kullanımlarında da görmek mümkündür. Diğer taraftan Farsça yazanların, ay ve gün gibi zaman dilimlerine yönelik kayıtsız kalmaları bir tarafa, yıllık tarihlendirmeleri bile oldukça sorunlu bir durum arz eder. X. yüzyıldan itibaren genel olarak tarihçiler, ilk iki buçuk asırlık döneme dair ilgilerini kaybetmişlerdir. Özellikle X. yüzyılın başlarındaki (908-932) siyasi felaketler, tarihyazımında değişime yol açmıştır. Tarih, artık siyasi bir basiret ve ahlaki nasihatin kaynağı haline gelmiştir (Humphreys, 2004, s. 166-168).

Vakanüvislik müessesesini göz önünde bulundurduğumuzda, vakanüvis tarihlerinde edebî tarih geleneğinin tesirinin izlerini daha kolay müşahede edebiliriz. Aslında Osmanlı tarih yazımı genel itibariyle kaynakların sıhhati açısından, diğer bir ifadeyle usul olarak ilmî tarihçiliği; üslup olarak ise edebî tarihçiliği tercih ederek her ikisini telif etme yoluna gitmiştir denebilir. Vakanüvislerin eserlerinde, ilmî tarihçilik okulunun etkilerini, tarihlendirmelerdeki vazıhlık hususiyetlerinde görmek mümkündür. Her ne kadar edebî üslubun seçilmesi vakanüvis tarafından tenkit edilse de nihai anlamda bunun üstesinden gelindiğini ileri sürmek güç olacaktır. Şanizade de bu tür bir üslup tarzını eleştirmektedir:

14 İslam tarihinde, gerçek anlamda zamandizimine ve coğrafyaya dayanan, yazılan malzemenin tenkit süzgecinden geçirildiği tarih ilmi, Medine'de tefsir ve hadisle uğraşan din âlimleri arasında ortaya çıkmıştır. Başlangıçta peygamberin hayatından bahseden "siyer" ve savaşlarından bahseden "megâzi" alanlarında çalışmalar yapılmıştır. Medine'de Hadisçi Tarih Okulu oluşurken Irak'ta Haberci Tarih Okulu ortaya çıkmıştır. Bk. Akbulut (2006, s. 11).

15 Şehname ve vakanüvis geleneğinin en başat özelliğinin bu olduğu söylenebilir. 
"Ifade-i hakikat-i mâ fi'l-bâl etmeye sa'y ve dikkatten ziyade, elfâz ve makâlde zinete ve fenn-i inşâda arz-ı maharete meyl ü rağbet ettikleridir. Zira riayet-i seci' ve kavâfî, teksîr-i kelamla hakk-ı tabiri ihlal ve ifsat ve kuvvet-i mefhum-i takriri, tagyîr ve berbat etmeye bir emr-i kâfidir" (Şanizade, 2008, s. 21). ${ }^{16}$

Ataullah Efendi, eserinin mukaddimesinde, "tarihi kemâ hüve hakkuhû zabt u tanzîme kâdir müverrihlerin"17 pek az olduğunu ifade eder. Tarih eseri telif edilirken duruma göre, "elfâz-ı mermûze", yani imalı ifadeler kullanmanın lazım geleceğinden bahseder. Sonrasında ise tarih yazımındaki kuralların, diğer sanatların kaideleri gibi olmakla birlikte her meslekte, kural ve usulün çokça olduğu ifade edilir (Şanizade, 2008, s. 24). Vakanüvislik geleneğinde edebî üslup yoğunluklu bir anlatım tercih edilmesi ve birtakım değerlendirmelerde şiir, atasözü, deyim, ayet ve hadis gibi alıntılara başvurulması, Şanizade'nin "elfâz-ı mermûze" şeklinde ifade ettiği üsluba karşılık gelmektedir ki bu tür bir üsluba, Tarih-i Şanizade'de sıklıkla başvurulduğu görülmüştür. ${ }^{18}$

Şanizade, diğer vakanüvisler gibi belirli bir geleneği devam ettirmekle birlikte kendine has olan bir üslup ve usul geliştirmiştir. Kitabının ilk cildinin başlarında tarih eserini kaleme alırken hesaplı hareket ederek doğruluğunu ortaya çıkardığı sırları tarafsız olarak kayıt altına aldığını; dünyanın değişmesini kaleme alan meşhur kemal ehli kimselerin sırlarını bizzat mütalaa ederek Devlet-i Aliyye'ye dair yazdıklarını sınayarak ve emin olarak, inceden inceye inceleyerek ezberlediği; kaydettiği ve haber verilmesi lazım gelen faydalı hakikatleri yeri geldiğinde çekemeyenleri dikkate almadan zikrettiğini ve cesaretinin de padişahın ihsan ve lütfuna itimadından kaynaklandığını söylemektedir (Şanizade, 2008, s. 61).

Şanizade, tarihinde üslup açısından iki tür dil tercih etmiştir. Birincisi, vakanüvis geleneğinin âdeta ayırt edici özelliği haline gelen belagatli edebî yoğunluğun öne çıkarıldı-

16 Gerçekte olanları ifade etmeye çalışmak yerine lafızlara, yazıda süse ve yazma sanatında maharetini göstermeye meyletmektedirler. Zira düz yazıda kafiye, kelime kalabalığı yaparak ifade edilecek olan gerçeği bozmaya ve anlatılanın anlamını değiştirme ve berbat etmeye yetecek bir eylemdir.

17 Tarihi, gerçekte olduğu şekilde kaydetmeye muktedir tarihçiler.

18 "Âfetü'r-riyâseti za'fu's-siyâseti" (Devletin afeti, güdülen siyasette zaaf göstermektir). Bk. Şanizade (2008, s. 717); "Ez-siyâset nizâm bâyed melik, bî-siyâset halel-pezîr buved" (Hükümdara düzgün siyaset gereklidir. Siyasetsizlik anarşi doğurur). Bk. Şanizade (2008, s. 716); “Ne der her sühan bahskerden revâst, hatâ ber-büzürgân giriften hatâst" (Her şeyi konuşmak caiz değildir. Büyüklerin hatasını bulmaya çalışmak ise hatadır). Bk. Şanizade (2008, s. 860); "Velâyetü'l-ahmakı serî'atü'zzevâli" (Ahmağın idareyi ele alması, çöküşü hızlandırır). Bk. Şanizade (2008, s. 875); "Der-zîr-i tîg-i hâdise ber-dest ü pâ me-zen, ki-în derd-râ be-cüz ser teslîm çâre nîst" (Kılıç altındaki olaya el ayak vurma! Çünkü bu derdin, başı teslim etmekten başka çaresi yoktur). Bk. Şanizade (2008, s. 932); "Çü fursat-yâft kârî cüz-gezîden nîst çûn mâreş, eğer bî-dest ü pâ bînî me-gû dervîş-i zalim-râ" (Bir fırsat bulunca yılan gibi ısırmaktan başka işi yoktur. Eğer elsiz ve ayaksız bir halde görürsen, onu zalim dervişe söyleme). Bk. Şanizade (2008, s. 978); "Ve râ'î'ş-şâti yahmî'z-zi'bü 'anhâ, fe-keyfe ize'r-ru'âtü lehâ ziyâbün" (Çoban, kuzuları kurttan korur; ama kurtlar çoban olursa yapılacak bir şey yoktur). Bk. Şanizade (2008, s. 979). 
ğı ve içeriğin geriye itildiği anlatı tarzıdır. Bu, vakanüvislerin edebî maharetlerine göre değişiklik gösterse de nihai anlamda hemen hemen aynı edebî yoğunluk, kurumun ortadan kaldırılmasına kadar devam etmiştir. ${ }^{19}$

Şanizade'nin tercih ettiği diğer üslup ise yer yer konuşma dilinin kullanıldığı daha az edebî yoğunluğu olan sade bir anlatım tarzıdır. Dilin edebî anlatım açısından yoğunlaştığı bölümleri de ikiye ayırmak yerinde olacaktır: İlk kısım, başta padişah olmak üzere diğer devlet ricalinin övüldüğü bölümlerden oluşur. Diğer kısımsa, başkaldırıda bulunmuş, karışıklığa sebebiyet vermiş, görevini kötüye kullanmış kişilerin cezalarına dair olan bölümlerdir. Buralarda, o şahıslara yönelik eleştiri getirilir; hakarete varan ifadeler edebî yoğunluklu cümlelerle bir arada bulunur. ${ }^{20}$

İkinci bölümde daha sade anlatımlar tercih edilmektedir. Bu tarz yerler, isim ve sıfat tamlamalarının seyrekleştiği daha hafif bir üslupla kendini gösterir. Bazen tamamen konuşma dili anlatıma hâkim olmaktadır. Bu kısımlarda genel olarak vakalar, o hadiseye şahit olan kişinin ifadeleriyle aktarılır. ${ }^{21}$ Hatta yerel unsurlar barındıran aktarımlar dahi söz konusu olabilmektedir. ${ }^{22}$ Şanizade, eserinin ikinci cildinde Ermenilerin Katolik mezhebine geçmelerinden bahsettiği bölümde, Osmanlı Devleti'ne yönelik uygun olmayan ifadeleri dillendiren kişilerin sürgün cezası alışlarını zikrederken "istenilen şeye ne kadar çaba sarf edilirse edilsin, takdir edilenden fazlası gerçekleşmez" diye çevrilebilecek yarı Ermenice, yarı Türkçe bir ibare mevcuttur. ${ }^{23}$ Aslında yerel ya da olaya has bir dilin kendisinde bulunduğu bir aktarım, Şanizade'nin kendine özgü ifade tarzının bir başka veçhesini oluşturmaktadır. ${ }^{24}$

19 Asrın sonlarında görev yapan Cevdet Paşa bile eserinde edebî üsluba dair değerlendirmelere yer vermek durumunda kalmıştır. Bk. Ahmet Cevdet (1312, s. 84).

20 Kendisine müracaat-ü itina eylemeyenler hakkında fem-i mârdan semm-rîz olan dehânını küşad ve dem-i akrepten tîz olan zebânını ıs'âd etmekle..." Bk. Şanizade (1290, s. 183). "Kendisine müracaat etmeyenler hakkında yılanın ağzından zehir saçar gibi olan ağzını açarak akrebin nefesinden hızlı olan dilini çıkarmakla..."

21 "Eğer Seyyidî Ali Bey, şu gemilerin üzerine beş gemiyle gönderilse, onların cümlesini bize esir eder, amma iş başkadır" Bk. Şanizade (2008, s. 47).

22 "Inç kadar cehd gıllemek murâda; nasîb çılla mukadderden ziyade" Bk. Şanizade (1290, s. 368).

23 Düzoğulları ve Anzavuroğulları arasında çıkan kavgadan bahsedildiği bir başka bölümde de “...çe. İnç kak gudes zo?" yani "...olmaz. Ne halt ediyorsun ulan?" ifadesi zikredilmektedir. Bk. Şanizade (2008, s. 939); "Aman efendi aman! Bu gavurların kastı yaman görünür. Şunlara rızamız ile varıp teslim olmayalım. Bari, ya selamet ya şehadet yolunda ölelim." şeklindeki aktarım cümlesi, konuşma dilindeki üsluba örnek olarak verilebilir. Şanizade (1290, s. 137).

24 Örneğin, Karaman Çarşısı'nda bulunan bir bakkalda, medrese talebesiyle dükkân sahibi arasında çıkan tartışmanın ardından olayın büyümesi neticesinde talebenin sürgüne gönderilmesi mevzubahis olmuştur. Şanizade, bu olayı aktarırken medrese talebelerinin tepkilerine de yer verir: Medreselerde tedris gören talebelerin toplanarak "Bu ne dimek! Bir bakkal gavuruna iki sille urmağla talebe-i ulûmu bu mertebe darba Madrûbî Hace bile gayr-ı razı ve hususan 'darabe zeydün amran' makûlesi..." şeklinde bir üslup seçerek hadiseyi eserinde kaydeder. Devamında ise, "Amr ile kavga 
Tablo 2.

Tarih-i Şanizade'deki Edebî ve Dinî Unsurların Dağılımı*

\section{$\begin{array}{llllll}\text { Dinî ve Edebî Alıntılar/Ciltler } & \text { Cilt } 1 & \text { Cilt } 2 & \text { Cilt } 3 & \text { Cilt } 4 & \text { Toplam }\end{array}$}

\begin{tabular}{lrrrrr}
\hline Arapça Özdeyiş ve Ifadeler & 46 & 55 & 46 & 38 & 185 \\
\hline Arapça Atasözleri & 25 & 133 & 54 & 54 & 266 \\
\hline Arapça Şiirler & 7 & 56 & 25 & 21 & 109 \\
\hline Arapça Deyimler & 4 & 6 & 5 & 0 & 15 \\
\hline Arapça Dualar & 13 & 28 & 25 & 9 & 75 \\
\hline Farsça Özdeyiş ve Ifadeler & 3 & 5 & 1 & 0 & 9 \\
\hline Farsça Atasözleri & 2 & 2 & 0 & 1 & 5 \\
\hline Farsça Şiirler & 32 & 122 & 76 & 37 & 267 \\
\hline Farsça Deyimler & 2 & 2 & 0 & 0 & 4 \\
\hline Farsça Dualar & 1 & 0 & 0 & 0 & 1 \\
\hline Türkçe Özdeyiş ve Ifadeler & 2 & 0 & 0 & 0 & 2 \\
\hline Türkçe Şiirler & 20 & 47 & 38 & 10 & 115 \\
\hline Ayetler & 46 & 70 & 42 & 31 & 189 \\
\hline Sahih Hadisler & 9 & 42 & 6 & 7 & 64 \\
\hline Mevzu Hadisler & 4 & 8 & 2 & 0 & 14 \\
\hline Ermenice Iffadeler & 0 & 1 & 1 & 0 & 2 \\
\hline Genel Toplam & & & & 1322 \\
\hline
\end{tabular}

Tarihsel metinlerdeki beyit alıntılarının belirli aralıklarla metne dâhil edilmesi, karşılıklı konuşma ya da mektuplarla aynı amaç doğrultusunda, yani tarihçinin kendi adına konuş-

eden Zeyd gibi öfkeyle bana saldıran bir nahivciyle başım derde girdi. Zeyd'in sürüklemesi sebebiyle başını kaldıramıyor. Zaten başında cer amili bulunurken kendini nasıl doğrultabilir" Bk. Şanizade (2008, s. 810). 'Darabe zeydün amran' nahiv ilminde (nahiv, Arapça dilbilgisinin sözdizimi kuralları ile i'rab bölümünü kapsayan bir ilimdir) kullanılan en meşhur örneklerden biridir. İlim talebesinin olayda adı geçmesi, Şanizade'nin bu tarz bir ifade şeklini tercih etmesine imkân tanımaktadır. Bk. Şanizade (1290, s. 359).

* Yukarıdaki çizelgede yer alan bilgiler (mezkûr çizelge oluşturulurken Ziya Yılmazer'in Şânî-zâde Târîhi isimli çevriyazısal çalışması esas alınmıştır), edebî anlatımın baskın bir şekilde Arapça ve Farsça'ya ait unsurlarla güçlendirildiğine işaret etmektedir. Türkçe unsurlar, eserin bütün ciltlerinde geri planda kalmaktadır. 
madan ya da herhangi bir değerlendirme yapmadan zikredilen olaylara veya şahıslara dair dolaysız yorum veya değerlendirme yapabilmesine imkân sağlamak için kullanılmasıyla irtibatlıdır. Kısaca ifade etmek gerekirse şiir, bir yorum vasıtası olarak müellifin kendisini güvenli bir şekilde başkaları üzerinden ifade etmesine imkân tanımıştır (Humphreys, 2004, s. 122). Tarih-i Şanizade'de, bu tür ifade tarzına sıklıkla başvurulmaktadır. ${ }^{25}$

Ataullah Efendi, eserini kaleme alırken düz yazıda kullandığı Arapça ağırıklı edebî üsluptaki şiir, atasözü ve deyimlerin çokluğu dikkat çekmektedir. Bunun yanında düz yazıdaki Farsça ifadeler, özellikle vakanüvis gelenekte çoğunlukla tercih edilen Farsça başlıklar, Arapçaya nazaran geri konumda kalmaktadır. Osmanlı tarih yazım kültüründe birtakım hususiyetler hemen hemen her dönemde devamlılık gösterse de hem yazım usulünde hem de konu dağılımında belli dönemlerde değişiklik olmuştur. Şanizade de bu duruma temas eder: "Tevarih-i atîkanın bazında mültezem, ancak fesahat ve bazı katl ü tedmîr-i eşkıyadan ibaret bazısında dahi ekser makâl, tarif-i ahval-i harb ü kıtal ve bazısında ise mültezem, kıdem-i emsâr u ümeme dair ahvaldir" (Şanizade, 2008, s. 22). ${ }^{26}$

İslam dünyasında, ilim adamlarının hayatını anlatan eserler yazılmış ve bu eserlerde, âlimlerin kimden ders aldıkları, hangi dersleri gördükleri zikredilmiştir. Buradaki amaç, ilmî malumatın kesintisiz bir zincir halinde (hadis rivayetlerinde olduğu gibi) nesilden nesile aktarılmasının temin edilmesidir. Bu tür çalışmalarda mezkûr ilim adamının hangi hocalarla çalıştığı, ne tür görevler deruhte ettiği, hangi eserleri yazdığı ve son

25 "Küllü inâ'in yetereşşahu bimâ fîhi" (Her kap içindekini sızdırır). Bk. Şanizade (2008, s. 69);"Her kücâ bâd ancâ berbâd" (Her nerede olursa orayı berbâd eyler). Bk. Şanizade (2008, s. 81); “Ân kes ki ne-dâned ü ne-dâned ki ne-dâned; Der-cehl-i mürekkeb ebedi'd-dehr be-mâned" (Bilmeyen o kimse, bilmediğini de bilmez. Tam cehalet dünyada ebedî kalır). Bk. Şanizade (2008, s. 97); "Men cenne sâ'aten lem yufık ebeden" (Bir an cinnet geçiren, sonsuza dek iflah olmaz). Bk. Şanizade (2008, s. 115); "Hüşt-dâr ki rüzgâr şûr-engîzest, Eymen me-nişîn ki tîg-i devrân tîzest; Der-kâm-ı tû ger zemâne lüvzîne nihed, Zinhâr fürû me-ber ki zehr âmizest" (Zaman kargaşayı tahrik ettiği için uyanık ol! Zamanın kılııı keskin olduğu için oturduğun yere pek güvenme! Zaman ağzına baklava bile koysa, zehir karışmış olduğu için sakın unutma!). Bk. Şanizade (2008, s. 132); "Bisyârî-i düzdân ez-müsâmaha-i şıhnest"(Yankesicilerin çokluğu, yöneticinin müsamahasındandır). Bk. Şanizade (2008, s. 365); "Sipahî heme kîne-ver çün sibâ,' velî çün behâyim ki der-ictimâ" (Ordu mensupları düşmana karşı yırtıcı hayvanlar gibi kindardır; fakat toplu halde iken dört ayaklı hayvan gibidirler). Bk. Şanizade (2008, s. 360); "en-Nâsü 'alâ sülûki mülûkihim" (İnsanlar, yöneticilerinin yaşantıları üzeredir). Bk. Şanizade (2008, s. 379); "İâ ednâke sultânen fe-zidhu, mine'ta'zîmi va'hzirhu ve râkıb, feme's-sultânu ille'l-bahru'ızemen, ve kurbü'l-bahri mâhzûru'l'avâkıbı" (Hükümdar sana yaklaştığı zaman saygını arttır, ondan sakın ve tetikte ol! Çünkü hükümdar, büyüklük bakımından denize benzer ve denizin kenarı sonuçları itibariyle mahzurludur). Bk. Şanizade (2008 s . 572); "Lâ yegurrannake mine's-sultâni karâbetün ve lâ uhuvvetün fe-inne ehakka'l-eşyâ' bi-tahrîkı'n-nâri akrabuhum minhâ"' (Sultanın akrabası olman, hatta kardeşi olman seni aldatmasın, çünkü ateşin yakmasına en elverişli olan ona en yakın olandır). Bk. Şanizade (2008, s. 633). Aynı şekilde daha birçok örnek zikretmek mümkündür. Bu anlamda Yılmazer'in çalışmasının ilk cildindeki 24, 45, 90, 106, 132, 142, 179, 184, 186, 199, 307, 308, 321, 328, 341, 359, 365, 369, 471, 472, $504,509,570,632,670,685$ ve 717 numaralı sayfalara müracaat edilebilir.

26 "Eski tarihlerin bazısı sadece bozulma ve bozguncuların yok edilmesinden bahsetmekte; bazısında da çoğunlukla yazılanlar savaşları anlatmakta; bazısı ise eski millet ve memleketlerin durumlarına dairdir." 
günleri hakkında bilgi verilir, bulunduğu takdirde birkaç kısa hikâye aktarılırdı. Her padişahın dönemini ve saltanat tarzını eksiksiz aktarabilmek için yazılan saltanat dönemlerinin akabinde, o döneme ait siyasi ve kültürel açıdan öne çıkmış kişilerin yaşam öyküleri eklenmiştir. Böyle tafsilatlı yaşamöyküsel malzemeye yer vermek Osmanlı tarihyazım geleneği içinde önemli bir yenilik olmuştur (Fleischer, 2009, s. 254).

XVI. yüzyıla gelindiğinde bu gelenek, Osmanlı tarih yazıcılığı içinde kendine sağlam bir mevki edinmişti. XVII. yüzyıldaysa, bir padişahın hüküm sürdüğü devirle ilgili aktarımların akabinde, aynı dönemde ölen önemli kişilerin hayat hikâyelerinin eklendiği oluyordu. Böylece iki tür, yani vakayiname ile tercüme-i hal bir araya getirilmiştir (Farooqhi, 2009, s. 243-244). Aynı şekilde Şanizade, yazdığı dönemde yaşamış ve devlet kademelerinde ya da medrese veya mektep gibi ilmî müesseselerde görev almış ilim adamlarının tercüme-i hallerini eserinde zikretmiştir. Şanizade'nin tarihi de vakayiname ile tercüme-i halin bir arada ele alındığı eserlere nitelik yönünden bir örnektir denebilir. Bu tarz, Arap tarih yazıcılığı içerisinde "vefâyât yazıcılığı" olarak geçmektedir.

Vakanüvis tarihlerinin en belirgin özelliği, vakayiname olarak yıllık dönemlendirmelerin merkeze alınması ve olayların bu çerçeve üzerine bina edilmesi olmuştur. Hadiselerin seçim ve dağılımına bakıldığında öncelikle göze çarpan vukuât-ı şettâ denilen alışılagelmiş olayların yoğun bir şekilde aktarımıdır. Bu başlık altında, saraydaki tören ve kutlamalar, İstanbul'a gelen giden önemli devlet erkânı hakkındaki haberler, ziyaretler, davetler gibi muayyen ve alışılagelmiş meseleler işlenir. Diğer taraftan eserlerin kendi dönemine bağlı olarak anlatının genelinde belli bir ya da birkaç konunun ağırlık kazandığı görülebilir. Şanizade'de söz konusu olan; yeniçerilerin isyanları, zorbalık ve zulümleri, Balkanlardaki isyanlar, özellikle de Rum isyanları ve devlet kademelerindeki yozlaşmadan kaynaklanan görev değişiklikleri, sürgünler ve idamlardır.

\section{Tablo 3.}

Tarih-i Şanizade'nin Ihtiva Ettiği Konuların Tasnifi

\begin{tabular}{llllll}
\hline Konu Dağılımı/Ciltler & Cilt 1 & Cilt 2 & Cilt 3 & Cilt 4 & Toplam \\
\hline Doğum Haberleri & 2 & 12 & 2 & - & 16 \\
\hline Ölüm Haberleri & 10 & 13 & 3 & 2 & 28 \\
\hline Tayin, Terfi ve Tevcihât & 55 & 49 & 16 & 9 & 129 \\
\hline Katl, İdamlar & 16 & 28 & 11 & 22 & 77 \\
\hline Aziller & 6 & 6 & 4 & 2 & 18 \\
\hline Sürgünler & 14 & 19 & 6 & 5 & 44 \\
\hline Layiha ve Vasiyetler & 3 & - & - & 4 & 7 \\
\hline Muhtelif Hadiseler & 10 & 8 & 8 & 19 & 45 \\
\hline Yangınlar & - & 2 & - & 2 & 4 \\
\hline Salgın Hastalıklar & - & 6 & - & - & 6 \\
\hline Sarayla İlgili Malumatlar & - & 4 & 1 & - & 5 \\
\hline
\end{tabular}




\begin{tabular}{|c|c|c|c|c|c|}
\hline İstanbul ile Alakalı Haberler & 7 & 7 & 2 & 7 & 23 \\
\hline Anadolu'ya dair Malumat & 1 & 6 & 2 & 2 & 11 \\
\hline Balkanlar ile İlgili Bilgiler & 5 & 10 & 4 & 4 & 23 \\
\hline Sel Baskınları & - & 1 & - & - & 1 \\
\hline Yeniçeri İsyan ve Zorbalıkları & 5 & 2 & 1 & 3 & 11 \\
\hline Tercüme-i Hal & 6 & 5 & 2 & 1 & 14 \\
\hline Ferman Suretleri & 22 & 25 & 9 & 11 & 67 \\
\hline Harp ve Ordu ile İlgili Haberler & 40 & 16 & 8 & 13 & 77 \\
\hline Ayan İsyan ve Zorbalıkları & 2 & 1 & 1 & 1 & 5 \\
\hline Ziyaret ve Teşrifler & 2 & - & - & - & 2 \\
\hline Tören ve Kutlamalar & 4 & 1 & 1 & 1 & 7 \\
\hline Tebdîlât ve Tahvilât & 14 & 14 & 3 & - & 31 \\
\hline İstidrâd ve Sâniha & 2 & 1 & 4 & 1 & 8 \\
\hline Davetler & 3 & - & - & - & 3 \\
\hline Antlaşma ve Yazışma Haberleri & 8 & 8 & 1 & 2 & 19 \\
\hline Antlaşma Metinleri & 2 & - & - & 1 & 3 \\
\hline Garib Vakalar & 2 & 1 & - & 1 & 4 \\
\hline Askerî Düzenleme ve Sevkiyatlar & 15 & 21 & 2 & 11 & 49 \\
\hline Avdetler & 9 & 11 & 2 & 3 & 25 \\
\hline İktisadi Malumatlar & 1 & 1 & 1 & 2 & 5 \\
\hline Arap Eyaletlerine Dair Malumat & 5 & 13 & 1 & 2 & 21 \\
\hline Takrirler-Tezkireler-Yaftalar & 9 & 1 & - & 3 & 13 \\
\hline Tıbbî Hadiseler & 1 & 1 & 1 & - & 3 \\
\hline Kavga ve Karışıklıklar & - & 3 & 7 & 4 & 14 \\
\hline Gayrimüslimler & - & - & 1 & 4 & 5 \\
\hline Anadolu'daki İsyanlar & - & 2 & 1 & 1 & 4 \\
\hline Mudhike ve Nükte & - & - & 2 & 1 & 3 \\
\hline Vukuât-ı Küsûf & - & 1 & 1 & 1 & 3 \\
\hline Balkanlardaki İsyan ve karışıklıklar & - & 8 & 4 & 14 & 26 \\
\hline Yıldızbilimsel İzâhât & 3 & 5 & 2 & 1 & 11 \\
\hline Avrupa'ya Dair Mevzular & - & - & 2 & 5 & 7 \\
\hline Yağma, Talan ve Soygunlar & - & 2 & - & 4 & 6 \\
\hline Genel Toplam & & & & & 883 \\
\hline
\end{tabular}

Şanizade'nin kitabında geçen her mevzuya başlık açmanın ya da bir takım konuları ortak bir isim altında toplamanın güçlüğünden bahsedecek olursak bu bilgi dökü- 
münün genel bir intiba bırakmak için birtakım sınırları kesin tutulamamakla birlikte oluşturulduğunu söylememiz gerekir. Örneğin, eserde geçen ve çizelgede kendisine en uygun düştüğü yer varsayılarak mezkûr tasnife alınan olaylar, bazen kısa ve öz bilgilerle bazen de tafsilatlı malumatlarla kaydedilmiştir. Dolayısıyla başlıkların veya açılan bölümlerin isimleri altında her zaman aynı tarz ve usulde bir bilgilendirmeyle karşılaşmak mümkün olmayabilir. Başlığın içermediği malumatların zikredilebilme ihtimali daha dikkatli bir tetkik ve tahlili icap ettirmekle beraber yazılan eserin düzen ve tertibatının durumunu da ortaya koymaktadır. Burada sorun, biraz da belirgin başlıklar kullanılmasından kaynaklanmaktadır. Neticede, vakanüvisin görevinin olay ve vakaları aktarmak olduğunu düşünsek bile Şanizade'nin hususi başlıklar altında hadiseleri aktarması, çok dağınık bir çizelgenin oluşmasına sebep olmuştur. Bunun haricinde, parçacı vaka anlatma ya da aktarma geleneği, hem anlatımı güçleştirme hem de genel bir çerçeve oluşturma açısından sorun teşkil etmektedir.

Vakanüvislerin nihai anlamda oluşturduğu bir yazım geleneği, bir şekilde Şanizade'de devam etmiştir. İçerik bakımından hükümdarın örtülü bir şekilde anlatının merkezinde yer aldığı, hadiselerin devlet merkezli bir tarzda seçilerek aktarıldığı, olay çemberinin ağırlıklı olarak öncelikle saray ve çevresi, sonrasında İstanbul ve akabinde taşra anlatılarından oluştuğu ${ }^{27}$ (taşra genel itibariyle siyasi ve içtimai olarak alışılmışın dışına çıktığı zaman dilimlerinde bu anlatıya dâhil edilmiştir $\left.{ }^{28}\right)$, üslup olarak ise üst bir dilin kurulduğu tarihyazım geleneğini II. Mahmud döneminde Şanizade temsil etmektedir. Gerek muhteviyat gerekse üslup açısından bir nevi üst dil kurulması, kaçınılmaz olarak vakanüvislerin ortaya koyduğu eserlerin, "üst bir kültür muhiti”ne hitap ettiği varsayımını kuvvetlendirmektedir.

\section{Sonuç}

Varlıkbilimsel ve bilgikuramsal zeminin Batı'da ortaya çıkan toplumsal bilimlerin etkisiyle değişmesi, tarihin ve tarih çalışmalarının hem asıl/kök hem de fer'leri/ uzantıları itibariyle de değişmesine yol açmıştır. 1700'lerin sonuna kadar Batı'da farklı bir dünya tasavvuru mevcut iken sonrasında günümüz "modern" dünya tasavvuru benimsenmiştir. Yani bu varoluşsal kırılma, sadece Batı-dışı toplumlara has olmayıp Batı'nın kendi tarihinde de yaşadığı varoluşsal bir kopuştur. Bu dönüşüm günümüzde dahi ilim camiasını etkisi altına almaya devam etmektedir.

27 Şehname ve vakanüvislik kurumu dışında da tarih kitapları yazmış olan Osmanlı müverrihleri olmuştur. Bunlar resmiyetin dışında olduklarından devrin haksızlıklarını ve halkın şikâyetlerini eserlerinde zikretmişlerdir. Tevarih-i Âl-i Osman'lar bu türe dâhil edilebilir. XV. yüzyıldan Edirneli Ruhî Çelebi, Behiştî ve Oruç bin Âdil, XVI. yüzyıldan Şeyhülislam İbn-i Kemal, Rüstem Paşa ve Lutfî Paşa, XVII. yüzyıldan Tezkireci Hasan Beyzâde'nin eserleri örnek olarak verilebilir. Bk. Özbilgen (2004, s. 596).

28 Geleneksel olarak tarih yazımı, çoksesli bir anlatıya sahip olarak görülmemiştir. Bunun sebebi olarak ise aşağı sınıfların genel anlamda bu anlatının dışında bırakılmış olmalarıdır. Bk. Traverso (2009, s. 24). 
Osmanlı, kelimenin tam anlamıyla kendine has bir medeniyet inşa etmişti. Bu medeniyetin köklerinin uzantıları Osmanlı hükümranlığının süresini aşmaktadır. İlmî ve kültürel anlamda ciddi bir tarihsel mirasın üzerine kurulması, tarih ilim geleneği kadar tarihinin de sınırlı olmadığını gözler önüne sermektedir. Bu uzun soluklu geçmişi taraflı olarak ele alan dünyevî-muhafazakâr bakış açısı, kendi geçmişine önyargılı bakan bir tarih tasavvuru geliştirmiştir. Binaenaleyh tarihî çalışmaların üç sac ayağından ikisi olan varlıkbilimsel ve bilgikuramsal unsurlar, tahlil ve tamir edilmeden tarihe ve tarih yazıcılığına dair bir usul inşa etmek pek muhal görünmektedir. Günümüz için Batı menşeinin dışında bir tarih düşünce ve tasavvurunun olmayışını bir nebze olsun açıklama çabası olan bu tahliller üzerinde çaba harcamak lüzumu, kendisini her geçen gün daha fazla hissettirmektedir.

Şanizade, bir vakanüvis olarak görevini icra etmiş ve kendi zamanını, müessesenin gereğine uygun bir şekilde başarılı olarak kaleme almıştır. Tababet ilmine sahip olan Şanizade'nin tıpla ilgili mevzuları zikretmesi, eserini muhteviyat yönünden zenginleştirmiştir. Dil ve üslup açısından edebî yoğunluğu devam ettiren Şanizade, dönemi itibariyle Yeniçeri zorbalıklarını, Rum isyanlarını, toplumsal yapıda ve devlet kademelerindeki ahlaki yozlaşmaları eserinde yoğun olarak işlemiştir. Klasik İslam tarih yazım geleneğinin önemli bir hususiyeti olan şiirler üzerinden eleştiride bulunma usulünü eserinde tercih etmiştir. Ve böylece tenkitlerin, yeri geldiğinde üstü kapalı bir şekilde ifade edilebilmesi mümkün olmuştur.

Şanizade, zımnen de olsa varoluşsal açıdan farklı bir bakış açısıyla tarihi ele almaktadır ki böylece günümüzde mevcut bulunan günümüz telakkisinden tamamen ayrılmaktadır. Şanizade, varlıkbilimsel yönden yaratılış üzerine temellendirilmiş düşünce tasavvurunu, bilgikuramsal açıdan ayet ve hadis gibi dinî referanslarla eserinde destekleme yoluna gitmiştir. Hem varlıkbilimsel hem de bilgikuramsal zemin, Şanizade'nin eserini günümüz yekpare varoluşsal tarih tasavvurundan keskin bir şekilde ayrı yerde konumlandırmamızı iktiza eder. Kaza, kader ve takdir-i ilahîye dayalı izahlar, bu bağlamda somut örnekler olarak karşımıza çıkmaktadır. Fizik dünyanın, metafizik taraflarıyla da açıklanması, Tarih-i Şanizade'yi varoluşsal olarak anlamlandırma yönünden zenginleştirmiştir. Bu mütevazı çalışma da nihai anlamda Batı́nın dünyevi varlıkbilimi ve bilgikuramı üzerinden kurup kurguladığı tarih tasavvurunu "mevcut" olanı açıklamada kifayet etmediği sorunsalı üzerinden yola çıkılarak yapılmaya çalışılmıştır. Görünen o ki umut verici ipuçlarını tarihin dehlizlerinden keşfedip çıkarmak, yoğun bir çabayı hâlihazırda ziyadesiyle hissettirmektir. Netice itibariyle tarih, mümkinâtın arız olan ahvalinden müteşekkil, insana taalluk eden durumları intiva etmektedir. Fakat asla sadece bu sınırlar içinde anlaşılamayacak kadar da varoluşsal mertebeleri kendisinde barındırır. 


\title{
Şanizade Mehmet Ataullah: An Example of Ottoman History Writing and Thought of History
}

\author{
Halil Ibrahim Erol*
}

Each civilization and culture has developed a view of history and a tradition of historical writing which are uniquely theirs. The Ottoman Empire too, in this regard, had a long-established record of writing history. Starting from its foundation, the Ottoman Empire employed several methods of keeping events on record, thus institutionalizing Gavazatname and Menakibname to that end. At the turn of the $18^{\text {th }}$ century, Şehnamecilik was replaced with Vakanuvislik, an institution whose members, called vakanuvis (chroniclers), maintained the Ottoman history writing tradition until the disintegration of the empire. In other words, Vakanuvislik is an official post, which formed under Divan-ı Humayun (Pakalın, 1983, p. 574-575). The institution which spanned two centuries (1699-1924), always had a vakanuvis in charge of history writing, beginning with Mustafa Na'îmâ and ending with Abdurrahman Şeref. Under this institution, all vakanuvises are charged to record the event taking place when they are on duty. But most of the time, they could not write down all events due to the different reasons (they made effort to complete the incomplete works of their predecessor). So, they had to transfer the documents related to their own time to the followers (Cevdet Paşa, 1986, p. 3).

Originally inspired from Arabic and Iranian record keeping traditions to a certain extent, the Ottoman historians eventually created a tradition uniquely theirs. Although chroniclers adhered to this history writing tradition in general, in many respects, they had the opportunity to express themselves within this tradition. Despite relatively regular methods of record keeping in terms of content and style, vakanuvises contributed with their points of view and style to the overall Ottoman history writing tradition.

This paper will study Şanizade Ataullah Efendi, who was an Ottoman chronicler during the reign of Mahmut II, and his work Tarih-i Şanizade (Şanizade's History), followed by a brief introduction to the roots of history writing tradition and its course throughout

* Res. Assist., Kırklareli University Department of History Correspondence: halilibrahimerol@gmail.com, Kırklareli Üniversitesi Fen - Edebiyat Fakültesi, Kavaklı, Kırklareli, Turkey. 
history. Şanizade and his work, Tarih-i Şanizade, occupy a central position in Ottoman history writing.

It is known that Şanizade was born about 1770 in Istanbul (Inal, 1988, p.111). According to another assertion, it is possible that he was born before 1771 (Zülfikar, 1991, p. 13). But these two claims do not contradict each other. Şanizade, a member of the class of scholars of Islamic Law (Ulama), after his graduation from madrasah, completed Ulama education and he had the highest rank (Karslızâde, 1314, p. 66). And then, he was appointed as a vak'anüvis between 1819 and 1825 during the reign of Mahmud II. He wrote down the events which took place between 1808 and 1921. Therefore he transferred the rest of the documents and papers of the 1821 - 1825 periods to Mehmed Esad Efendi (Kütükoğlu, 1994, p. 106). The manuscripts of Tarih-i Şanizade are available in different libraries of Turkey (Yılmazer, 2008, p. LXII).

Table 1.

The Range of Tarih-i Şanizade with Regard to Years and Volumes*

\begin{tabular}{lll}
\hline Volumes & Time Intervals & Pages \\
\hline Volume 1 & $1808-1811$ & $8+409$ \\
\hline Volume 2 & $1811-1818$ & $8+425$ \\
\hline Volume 3 & $1818-1821$ & $4+216$ \\
\hline Volume 4 & 1821 & $4+208$ \\
\hline
\end{tabular}

When Şanizade was writing his book, he used many different resources and made use of literal quotations to explain and clarify the events and to comment on issues. The resources used by Şanizade can be roughly separated into two parts: written and verbal. Verbal resources are very rare and as reliable as written resources. Written resources can also be divided into two: official documents and previously written history books (Yılmazer, 2008, p. LXXI).

In the introduction to his book, Şanizade mentions his own ideas about history and divides history into three categories: authentic and true incidents, untrue and unreal events, and thirdly history built over rumors. This kind of history loses its authenticity due to delusions and imagination of the human mind. (Şanizade, 2008, p. 14). On the other hand, Şanizade separates history into two parts in terms of content: sacred histories and general histories.' The sacred one comprises of Prophet Mohammed's

* According to the table, it is obvious that historians could write down incidents more detailed when they record the events which are closer to them. Woodhead also states that Lokman and other historians composed the incidents closer to their time more detailed. See Woodhead (1983, p. 174-175).

1 Ahmet Mithat separates similarly history into three parts. See Nakıp (2006, p. 56, 83). 
life, anecdotes of other prophets, and stories of saints. Their resources are composed of divine and supra-mundane books, prophet's witnesses and the abstruse wisdom of exalted people. General histories discuss states, their administrational conditions, structure of societies and past events (Şanizade, 2008, p. 15).

According to Şanizade, old people should narrate the events and stories of their own time with their realities. Otherwise, these realities would lose their ability or possibility to be passed on to the next generations and they would eventually vanish (Şanizade, 2008, p. 15). Therefore, events need to be written down as soon as possible. It can be said that the institution of vakanuvis properly endeavored to accomplish this goal for two hundred years.

Şanizade discusses three pieces of evidence about the past which are based on some resources that are impossible to deny. The first evidence consists of observatory registers of Babylon. The second is the Chinese observatory registers as a counterpart of Babylon. And the last one is the inscriptions discovered by Thomas Howard (15851646) on Bare Island in the Mediterranean. As well as these three pieces of evidence, Şanizade also mentions the Pyramids in Egypt. According to Şanizade, this evidence illustrate people's past. After explaining these, Şanizade claims that the events preceded this evidence cannot be known by people. Therefore, all of them can be learned or discovered by people merely through revelations, hadiths, and the information given by divine books and prophets.

These explanations give us the opportunity to see the ontological stand of Şanizade. In the introduction to his book, Şanizade discusses these issues and deals with history in terms of a theoretical base by commenting on it ontologically and epistemologically. This is not a common practice among vakanuvises. At that point, the historical viewpoint of vakanuvises separates not only epistemologically but also epistemologically from modern historiography. For example, Şanizade claims that the Creator has the absolute power and history happens within the framework of His law and system (Şanizade, 2008, p. 33). So, history is directly related to God and His creation. This ontological standpoint easily distinguishes from today's modern and secular historiography.

Ottoman historiography as a history writing tradition can be evaluated within two categories: The first one is "scientific" historiography, which can also be called Islamic historiography. The other is literary historiography. The second tradition emerged in the period when ancient Persian legends came about anew. In the Persian literary historiography, historians generally did not pay much attention to the resources. They rather preferred rhetorical narration and intense literary styles. Both traditions influenced Ottoman historiography. For example the influence of literary historiog- 
raphy over the Ottoman tradition can be easily seen in the case of the institution of vakanuvis, However, this style was generally criticized by vakanuvises. ${ }^{2}$ Şanizade also criticized the rhetorical manner. He asserted that using ornaments in expression and rhetorical style in writing damages the reality, and inevitably changes the meaning of events. However, almost all vakanuvises narrated events oratorically and wrote their histories rhetorically.

Şanizade, in his history book, preferred two kinds of language: firstly, he preferred to write down incidents rhetorically, applying that style in words of praise, especially when he was talking about the Sultan or important figures around him. He also criticized some people in this rhetorical fashion. In this kind of writing style, the content of events was pushed into the background and literary expression was emphasized. Secondly, Şanizade chose to use spoken language in some parts of his history book. These passages are made up of ordinary people's witnesses of some events. The dialogues cited by Şanizade have local dialects and accents. For example, there are some semi- Armenian- Turkish expressions in the passage where Şanizade writes about the Catholic Church (Şanizade, 2008, p. 939).

Table 2.

The Range of Literary and Religious Elements in Tarih-i Şanizade

\begin{tabular}{lccccc}
\hline \multicolumn{1}{c}{$\begin{array}{c}\text { Religious and Literary } \\
\text { Quotations/Volumes }\end{array}$} & $\mathbf{1}$ & $\mathbf{2}$ & $\mathbf{3}$ & $\mathbf{4}$ & Total \\
\hline Arabic Maxims and Expressions & 46 & 55 & 46 & 38 & 185 \\
\hline Arabic Proverbs & 25 & 133 & 54 & 54 & 266 \\
\hline Arabic Poems & 7 & 56 & 25 & 21 & 109 \\
\hline Arabic Idioms & 4 & 6 & 5 & 0 & 15 \\
\hline Arabic Prayers & 13 & 28 & 25 & 9 & 75 \\
\hline Persian Maxims and Expressions & 3 & 5 & 1 & 0 & 9 \\
\hline Persian Proverbs & 2 & 2 & 0 & 1 & 5 \\
\hline Persian Poems & 32 & 122 & 76 & 37 & 267 \\
\hline Persian Idioms & 2 & 2 & 0 & 0 & 4 \\
\hline Persian Prayers & 1 & 0 & 0 & 0 & 1 \\
\hline Turkish Maxims and Expressions & 2 & 0 & 0 & 0 & 2 \\
\hline Turkish Poems & 20 & 47 & 38 & 10 & 115 \\
\hline
\end{tabular}

2 Ahmet Cevdet criticized the rhetorical manner in this book too. See Cevdet Paşa (1312, p. 84). 


\begin{tabular}{lccccc}
\hline Quran Verses & 46 & 70 & 42 & 31 & 189 \\
\hline Valid Hadiths & 9 & 42 & 6 & 7 & 64 \\
\hline Fake Hadiths & 4 & 8 & 2 & 0 & 14 \\
\hline Armenian Expressions & 0 & 1 & 1 & 0 & 2 \\
\hline Final Total & & & & & 1322 \\
\hline
\end{tabular}

The table above shows us the literary aspects of Tarih-i Şanizade and exhibits the density of literary quotations applied throughout the four volumes. In fact, these quotations were not used randomly; on the contrary, they were used to provide the opportunity to evaluate and criticize indirectly the persons or events told within the text. To put it in a nutshell, using quotations such as poems as a medium of evaluation could give the authors an opportunity to express themselves safely through the words of other people (Humphreys, 2004, p, 122).

The writing tradition instituted by vakanuvises was also maintained by Şanizade. In this fashion of history writing, the Sultan was put tacitly into the center of narrative, the events were picked up as the state-centered, and the density of events shaped by the court and its circles and countryside was partially told. On the other hand, to cite the Sultan's period and his reign completely, historians added to their books some people's biographies who are culturally and politically very important persons in that time. Giving a space such detailed biographical material in Ottoman history-writing tradition became a significant innovation (Fleischer, 2009, p. 254). Thus, writing history and curricula vitae were brought close together (Farooghi, 2009, p. 243-244). Şanizade's history is also an example of this kind of history-writing. Especially, he wrote down some prominent people's biographies from Ulama class in his book.

During the reign of Mahmud II, this history-writing tradition was represented by Şanizade as a vakanuvis. Şanizade deals with history from a different point of view, distinguished from today's modern and secular considerations. It is important to say that Şanizade addresses history ontologically, grounding it with the Creation. In terms of epistemology, he supported his views and evaluations by religious citations like Quran verses and hadiths. The explanations based on predestination, destiny and fate can be given as some examples related to his historical understanding. In conclusion, history is composed of different conditions of possibilities. However it contains ontological hierarchy which can only be undestood within its own limits. 


\section{Kaynakça / References}

Akbulut, U. (2006). Osmanlı tarih yazıcılarına göre tarih ve tarihçi. Yayınlanmamış doktora tezi, Atatürk Üniversitesi, Sosyal Bilimler Enstitüsü, Erzurum.

Beyhan, M. A. (1995). Şânizâde tarihi'nin kaynaklarından Câbî tarihi. The Journal of Ottoman Studies, XV, 239-283.

Cevdet Paşa, A. (1312). Tarih-i Cevdet (c. I). Dersaadet: Matbaa-i Osmaniye.

Cevdet Paşa, A. (1986). Tezâkir (haz. C. Baysun, c. I). Ankara: Türk Tarih Kurumu Basımevi.

Faroqhi, S. (2009). Osmanlı tarihi nasıl incelenir? (çev. Z. Altok). İstanbul: Tarih Vakfı Yurt Yayınları.

Fleischer, C. H. (2009).Tarihçi Mustafa Ali bir Osmanlı aydın ve bürokratı 1541-1600 (çev. A. Ortaç). İstanbul: Tarih Vakfı Yayınları.

Humphreys, R., s. (2004). İslam tarih metodolojisi: Bir sosyal tarih uygulaması (çev. M. Bedir ve F. Aydın). İstanbul: Litera Yayıncılık.

İnal, M. K. (1988). Son asır Türk şairleri (c. I). İstanbul: Dergâh Yayınları.

Karslızâde, C. M. (1314). Ayine-i zürefâ. Dersaâdet: İkdam.

Kütükoğlu, B. (1994). Vekayi'nüvis makaleler. İstanbul: İstanbul Fetih Cemiyeti Yayınları.

Şanizade, M. A. (1290). Tarih-i Şanizade (c. 1-4). Dersaadet: Ceride-i Havadis Matbaası.

Şanizade, M. A. (2008). Şânî-zâde Târîhi (yay. haz. Z. Yılmazer, c. 1-2). İstanbul: Çamlıca Yayınları.

Nakıp, T. (2006). Osmanlı Devleti'nde geç dönem tarih-i umûmîler. Yayınlanmamış yüksek lisans tezi, Marmara Üniversitesi, Türkiyat Araştırmaları Enstitüsü, İstanbul.

Ömer Efendi, C. (2003). Cabi Tarihi: Tarih-i Sultan Selim-i Salis ve Mahmud-ı Sani (haz. M. A. Beyhan). Ankara: Türk Tarih Kurumu.

Özbilgen, E. (2004). Bütün yönleriyle Osmanlı: Âdâb-ı Osmâniyye. İstanbul: İz Yayıncılık.

Pakalın, M. (1983). Osmanlı tarih deyimleri ve terimleri sözlüğü. Ankara: MEB.

Traverso, E. (2009). Geçmişi kullanma kılavuzu: Tarih, bellek, politika (çev. I. Ergüden). İstanbul: Versus Kitap.

Unan, F. (2003). Osmanlı medrese uleması: Ilim anlayışı ve ilmî verim. Koomduk İlimder Jurnalı Sosyal Bilimler Dergisi, 5, 14-34.

Woodhead, C. (1983). An experiment in official historiography: The post of Şehnâmeci in the Ottoman Empire. Wiener Zeitschrift für die Kunde des Mongenlandes, 75, 157-182.

Yılmazer, Z. (2008). Önsöz. (yay. haz. Z. Yılmazer), Şânî-zâde Târîhi içinde (XXVII-CXII). İstanbul: Çamlıca Yayınları.

Zülfikar, B. (1991). Şanizade, hayatı ve eserleri. İstanbul: Özel Yayınları. 